\title{
Problem-based learning (PBL), an important paradigm for bioinformatics education
}

\section{Opinion}

As a practicing bioinformatics since 2004, problem solving has been both a fundamental skill and recurring theme. In one way or another, I feel like a handyman or a go-to person for anything interfacing between experimental biology and computing. This can take the form of 5-minute show-and-tell - How can I run BLAST against a mouse genome? Or it can be something more elaborate How can I extend MapMan ${ }^{1}$ for my tobacco research? The latter is one of the sources of a bioinformatics research and/or development project, which resulted Ling et al. ${ }^{2}$ In other and perhaps more extreme cases, I had been approached to disinfect a computer from computer viruses and malwares. To a certain extent, bioinformaticists represents one of the final lines for computing advice, at least in my personal experience. As such, I often find myself given problems to solve rather than finding my own problems to tackle. Hence, problem solving becomes a recurring theme over the last one and a half decade. Problem solving as a core skill in bioinformatics is also supported by Jungck et al. ${ }^{3}$ Therefore, it is imperative that bioinformatics education consists of substantial amount of hands-on and minds-on activities. ${ }^{4}$

The requirement for hands-on and minds-on activities in bioinformatics education renders it suitable to employ ProblemBased Learning (PBL). Hmelo-Silver ${ }^{5}$ defines PBL as an instructional method where students learn through problem solving by engaging in self-directed learning and the process is facilitated, rather than providing knowledge, by the teacher. A common term that exist in the literature with PBL is Project-Based Learning (PtBL). In many instances, PtBL is also abbreviated to PBL; hence, leading to much confusion. Hong et al., ${ }^{6}$ acknowledge that the boundary between PBL and PtBL is fussy as both can complement each other, and conclude that both PBL and PtBL have similar conditions for successful application. I tend to use PBL as the overarching umbrella for all instructional methods involving problem solving and facilitated selfdirected learning. Hence, I prefer to use PBL in a very broad sense.

In my opinion, PBL should be an important component of bioinformatics education for three reasons. Firstly, the problem is given. This is common occurrence that I witness as a practicing bioinformaticist where I act as informal bioinformatics consultant to other projects. Secondly, the result or outcome is generally defined. The researcher or experimentalist seeking help generally have a defined outcome that he/she wants to achieve, or to provide supporting evidence for an outcome among many possible outcomes. Thirdly, the only flexibility that the bioinformaticist can maneuver is the route from the question to the outcome(s), the problem-solving aspect. Furthermore, formulating a method to solve the given problem is at the level of evaluation on Revised Bloom's Taxonomy. ${ }^{\text {? }}$

Depending on the problem given, the solution can be multifaceted. For example, given a DNA sequence, what may be the possible functions of the peptide? Student will need to use determine which of the 6 frames translation is likely to give a functional protein, what signal and localization sequences are on the protein, what are the

\author{
Volume 5 Issue 4 - 2017
}

\author{
Maurice HT Ling ${ }^{1,2}$ \\ 'Colossus Technologies LLP, Republic of Singapore \\ ${ }^{2}$ School of Bio Sciences, The University of Melbourne, Australia
}

\begin{abstract}
Correspondence: Maurice HT Ling, Colossus Technologies LLP,Address: 8 Burns Road, Trivex, Singapore 369977, Republic of Singapore, Tel +6596669233 ,

Email mauriceling@colossus-tech.com
\end{abstract}

Received: April 24, 2016 | Published: April 24, 2017

protein domains found, and what do the set of protein domains mean? Other students may include BLAST to get insights from homologous proteins or examine the promoter region of the protein. Yet, other students may explore gene expression databases, such as Gene Expression Omnibus, to gain insights by finding which genes are positively or negatively correlated with this specific protein, or under what conditions will this gene be down-regulated or up-regulated. If a class is divided into groups to work on this protein, it will be interesting to see the differences in approach and more importantly, get the groups to perform self-evaluation as to why certain methods are chosen or left out.

Hence, PBL will be a useful educational paradigm to build crucial problem-solving skills for the aspiring bioinformaticist. Several successful cases of PBL in bioinformatics education had been reported in the literature. ${ }^{8,9}$ Therefore, it is worth a try.

\section{Acknowledgements}

None.

\section{Conflict of interest}

The author declares no conflict of interest.

\section{References}

1. Thimm O, Bläsing $\mathrm{O}$, Gibon $\mathrm{Y}$, et al. MAPMAN: a user-driven tool to display genomics data sets onto diagrams of metabolic pathways and other biological processes. Plant J. 2004;37(6):914-939.

2. Ling MH, Rabara RC, Tripathi P, et al. Extending MapMan Ontology to Tobacco for Visualization of Gene Expression. Dataset Pap Biol. 2013;2013:pii. 706465.

3. Jungck JR, Donovan SS, Weisstein AE, et al. Bioinformatics education dissemination with an evolutionary problem solving perspective. Brief Bioinform. 2010;11(6):570-581.

4. Machluf Y, Yarden A. Integrating bioinformatics into senior high school: design principles and implications. Brief Bioinform. 2013;14(5):648660

5. Hmelo-Silver CE. Problem-Based Learning: What and How Do Students Learn? Educational Psychology Review. 2004;16(3):235-266. 
6. Hong JC, Lin CL, Huang HC. The Comparison of Problem-Based Learning (PmBL) Model and Project-Based Learning (PtBL) Model. In: International Conference on Engineering Education, 2007.

7. Nkhoma M, Lam T, Richardson J, et al. Developing case-based learning activities based on the revised Bloom's Taxonomy. Vietnam: Proceedings of Informing Science \& IT Education Conference; 2016. p. 85-93.
8. Marques I, Almeida P, Alves R, et al. Bioinformatics Projects Supporting Life-Sciences Learning in High Schools. PLoS Comput Biol. 2014;10(1):e1003404.

9. Nunes R, Barbosa de Almeida Júnior E, Pessoa Pinto de Menezes I, et al. Learning nucleic acids solving by bioinformatics problems. Biochem Mol Biol Educ. 2015;43(5):377-383. 